\title{
In Situ Lead Status
}

National Cancer Institute

\section{Source}

National Cancer Institute. In Situ Lead Status. NCI Thesaurus. Code C101240.

The state of an insulated wire designed to conduct energy from an electrical device to an anatomic site. (ACC) 